\title{
IMPLEMENTASI KEBIJAKAN PENGELOLAAN PERTAMANAN DI KOTA PALANGKA RAYA PROVINSI KALIMANTAN TENGAH
}

\author{
Implementation of Park Management Policies \\ in Palangka Raya City, Central Kalimantan Province
}

\section{Reza Pahlawan*}

Edy Andrean

\author{
Universitas Muhammadiyah \\ Palangkaraya, Palangka Raya, Central \\ Kalimantan, Indonesia \\ email: \\ reza.pahlawan@umpalangkaraya.ac.id
}

\begin{abstract}
Abstrak
Penelitian ini bertujuan untuk mengetahui dan mendeskripsikan pelaksanan kebijakan pengelolaan pertamanan di Kota Palangka Raya melalui Peraturan Daerah Nomor 03 Tahun 2006 dalam rangka menciptakan kondisi pertamanan yang bermanfaat. Metode penelitian yang digunakan adalah deskriptif kualitatif. Dalam hal ini peneliti ingin menggambarkan dan juga menjelaskan tentang fenomena yang terjadi terkait dengan masalah pertamanan yang masih cukup kurang pengelolaanya. Sumber data primer dari penelitian ini adalah masyarakat Kota Palangka Raya dan Pada Dinas Cipta Karya Tata Ruang dan Perumahan.

Hasil penelitian ini menujukan ini menunjukan masih rendahnya kesadaran dan kemauan masyarakat untuk mau berpartisipasi bersama-sama menjaga dan mengelola pertamanan. Selain itu factor komunikasi, pengawasan serta sumber daya manusia yang dimiliki oleh Dinas terkait sebagai pelaksanaan dari kebijakan tersebut kepada masyarakat dirasakan masih belum berjalan secara maksimal.
\end{abstract}

Kata Kunci:

Impementasi

Kebijakan

Pengelolaan

Taman

\section{Keywords:}

Implementation

Policy

Management

Parks

\section{Accepted}

June 2015

\section{Published}

October 2015

\begin{abstract}
This study aims to find out and describe the implementation of garden management policies in the City of Palangka Raya through Regional Regulation No. 03 of 2006 in order to create useful gardening conditions. The research method used is descriptive qualitative. In this case, the researcher wants to describe and also explain the phenomena that occur related to gardening problems that are still lacking in management. The primary data source of this research is the people of the City of Palangka Raya and the Office of Cipta Karya, Spatial Planning and Housing.

The results of this study address this shows that there is still low awareness and willingness of the community to participate together in maintaining and managing parks. In addition, the communication, supervision and human resources factors that are owned by the related Office as the implementation of the policy to the public is felt to have not run optimally.
\end{abstract}

\section{PENDAHULUAN}

Peran taman kota menjadi sangat penting dalam rangka memberikan fungsi edukasi kepada masyarakat, khususnya anak-anak. Dengan potensi luas wilayah yang sebagian besar masih belum terjamah dan berpeluang besar untuk dapat dijadikan sebagai area pertamanan, pemerintah kota palangkaraya diharapkan dapat memanfaatkan serta menyediakan hal tersebut dengan sebaik mungkin. Bukan hanya sebagai wahana atau tempat bermain, tempat rekreasi, serta menjadi tempat untuk menghilangkan kepenatan oleh rutinitas sehari-hari, taman kota juga diharapkan mampu memberikan dampak positif lainnya, seperti dimanfaatkan sebagai tempat belajar, edukasi, penanaman nilai-nilai cinta terhadap lingkungan, tempat diskusi public dan lain sebagainya.

Keberadaan taman kota sangat diharapkan oleh sebagian besar warga kota Palangka Raya dan segala bentuk perbaikan atas beberapa taman kota yang ada di Kota Palangka Raya, seperti pada taman Kota Palangka Raya yaitu taman bundaran, taman median, serta taman kota sangat disambut baik oleh warga kota 
palangka raya. Hal tersebut membuktikan bahwa keberadaan taman kota masih sangat menjadi harapan yang ditunggu-tunggu oleh warga kota Palangka Raya.

Pada dasarnya keberadaan taman kota yang tertata rapi, cantik, nyaman, sehat, dan aman memberikan ketenangan dan nilai estetika bagi masyarakat disekitarnya. Ditengah hiruk pikuk aktifitas perkotaan yang semakin hari semakin padat dengan produksi polusi baik di udara, air, maupun tanahyang semakin meningkat, disinilah fungsi keberadaan taman kota dan ruang terbuka hijau menjadi sangat diperlukan.

Saat ini kondisi taman kota di Palangka Raya dapat dikatakan dalam kondisi yang membaik dari sebelumnya. Dimana pada beberapa bulan yang lalu kita masih menjumpai kondisi taman yang berantakan, tidak terawat, terdapat sampah-sampah, tumbuhan dan tanaman yang kering, bangunan atau sarana dan prasarana yang rusak dan terlibat kusam, berbeda dengan kondisi saat ini dan dimana kondisi pertamanan sudah diperbaiki, dan dibenahi, dan ditanami oleh tanaman-tanaman penghijau, lampu-lampu hias dan reifrelif yang berfungsi memperindah taman kota.

Namun hal itu dinilai masih belum memenuhi tuntutan dan keinginan masyarakat. Berdasarkan pengamatan dalam pengelolaan pertamanan dan juga anturan ketentuan dalam Peraturan Daerah Nomor 03 Tahun 2006 pemerintah daerah seharusnya wajib mengadakan sarana dan prasarana kebersihan pertamanan seperti tempat sampah ditempat-tempat umum dan jalan umum, membuat taman peneduh atau pelindung, adanya petugas kebersihan taman kota dan peralatan kerjanya. Namun kenyataannya masih ada sebagian taman kota yang belum terjamah pengelolaanya, kurangnya pepohonan yang rindang, masih kurangnya tersedianya tempat sampah baik di taman, tempattempat umum, dan dijalan umum, masih kurangnya keterbatasan petugas pengelolaan pertamanan terlebih bagi kurangnya kesadaran masyarakat untuk merawat dan menjaga pertamanan masih minim.
Namun hal tersebut tidak diperhatikan oleh sebagian masyarakat dan seolah-olah menjadi hal yang tidak begitu penting, selain itu saluran-saluran irigasi air yang tidak berfungsi sehingga menyebabkan genangan air di badan jalan seperti diperhatikan dimedia cetak harian kalteng pos.

Implementasi adalah suatu tindakan atau pelaksanaan dari sebuah rencana yang sudah disusun secara matang dan terperinci. Dalam artian sederhana implementasi dapat dipahami sebagai pelaksanaan atau kegiatan, Hinggis (Pasolong, 2011:57) mendefenisikan "implementasi sebagai rangkuman dari berbagai kegiatan yang didalamnya sumber daya manusia menggunakan sumber daya lain untuk mencapai sasaran strategis. Sedangkan menurut Pressman dan Wildavsky (Tangkilisan, 2013:17) berpendapat bahwa implementasi dapat diartikan sebagai interaksi antara penyusunan tujuan dengan sarana-sarana tindakan dalam mencapai tujuan tersebut atau kemampuan untuk menghubungkan dalam hubungan kausal antara yang diinginkan dengan cara untuk mencapainya. Pendapat lainnya seorang ahli Patton dan Sawicki (Tangkilisan, 2003:9) mengemukakan bahwa “Implementasi berkaitan dengan kegiatan yang diarahkan untuk merealisasikan program, dimana pada posisi ini eksekutif mengatur cara untuk mengorganisir, menginterprestasikan dan menerapkan kebijakan yang telah diseleksi. Sehingga dengan mengorganisir, seorang eksekutif mampu mengatur secara efektif dan efisien sumber daya, unit-unit dan teknik yang dapat mendukung pelaksanaan program, serta melakukan interprestasi terhadap perencanaan yang telah dibuat, dan petunjuk

Menurut Van Meter dan Van Horn (Winarno, 2007:163) mengetengahkan beberapa unsur yang mungkin berpengaruh terhadap suatu organisasi dalam mengimplementasikan kebijakan :

I. Kompetensi dan ukuran staf suatu badan 
2. Tingkat pengawasan hierarki terhadap keputusankeputusan sub unit dan proses-proses dalam badan-badan pelaksanaan

3. Sumber-sumber politik suatu organisasi (misalnya dukungan diantara anggota-anggota legislative dan eksekutif)

4. Vitalitas suatu organisasi

5. Tingkat komunikasi-komunikasi terbuka yang didefinisikan sebagai jaringan kerja komunikasi horizontal dan vertical secara bebas serta tingkat kebebasan yang secara relatif tinggi dalam komunikasi dengan individu-individu diluar organisasi

6. Kaitan formal dan informal suatu badan dengan badan pembuat keputusan atau pelaksana keputusan.

Menurut Ripplry dan Franklin (Tangkilisan, 2003:2I-22) menyatakan keberhasilan implementasi kebijakan program dan ditinjau dari tiga factor yaitu :

a. Perprktif Kepatuha, Yang mengukur implementasi dari kepatuhan strate level burcancrats terhadap atas mereka.

b. Keberhasilan implementasi dapat diukur dari kelancaran rutinitas dan tiadanya persoalan.

c. Implementasi yang berhasil mengarah kepada kinerja yang memuaskan semua pihak terutama kelompok penerima manfaat yang diharapkan.

Faktor yang menyebabkan implementasi kebijakan yang gagal menurut Peters (Tangkilisan, 2003-22) disebabkan beberapa factor :

a. Informasi

Kekurangan informasi dengan mudah mengakibatkan adanya gambaran yang kurang tepat baik kepada objek kebijakan maupun kepada para pelaksanan dari isi kebijakan yang akan dilaksanakannya dan hasil-hasil dari kebijakan itu.

b. Isi Kebijakan Impelementasi kebijakan dapat gagal karena masih samarnya isi atau tujuan kebijakan atau ketidaktepatan atau ketidaktegasan intern atau ekstern atau kebijakan itu sendiri, menunjukan adanya kekurangan yang sangat bearti atau adanya kekurangan yang menyangkut sumber daya pembantu.

c. Dukungan

Implementasi kebijakan public akan sangat sulit bila pada pelaksanaanya tidak cukup dukungan untuk kebijakan tersebut.

d. Pembagian Potensi

$\mathrm{Hal}$ ini terkait dengan pembagian potensi diantaranya para actor implementasi dan juga mengenai organisasi pelaksana dalam kaitannya dengan diferensiasi tugas dan wewenang.

\section{Konsep Pengelolaan Pertamanan Kota}

Mengenai konsep pengelolaan pertamanan di ambil dari sumber profil Pertamanan Kota Palangka Raya Dinas Tata Kota Pembangunan dan Pertamanan Kota Palangka Raya tahun 2006. Dalam hal ini konsep pengelolaan pertamanan dijelaskan sebagai berikut :

I. Taman Kota Bagian dari RTH

2. Konsep Terhadap Kondisi Tanah

3. Konsep Tata Hijau (pemilihan jenis tanaman)

4. Arsitektural

Kebijakan Pemerintah Daerah Kota Palangka Raya tentang pengelolaan Pertamanan

Untuk pengelolaan pertamanan di Kota Palangka Raya, maka pemerintah kota mengeluarakan kebijakan untuk menangani masalam dalam pengelolaan pertamanan. Adapun kebijakan yang mengatur tentang pengelolaan pertamanan dituangkan melalui peraturan daerah (PERDA) Kota Palangka Raya Nomor 03 Tahun 2006 tentang pengelolaan kebersihan lingkungan dan pertamanan wilayah Kota Palangka Raya.

\section{METODOLOGI}

Penelitian ini menggunakan pendekatan kualitatif yaitu penelitian yang bermaksud untuk memahami fenomena tentang apa yang di pahami oleh subjek penelitian, 
misalnya perilaku, persepsi, motivasi, tindakan dan lain sebagainya (Herdiansyah, 2009). Hal ini karena penelitian ini ingin mengetahui keseluruhan tentang implementasi kebijakan pengelolaan pertamanan di Kota Palangka Raya maka dalam penelitian ini pendekatan yang dilakukan adalah memulai pendekatan kaulitatif. Artinya data yang dikumpulkan bukan berupa angka-angka, melainkan data tersebut berasal dari naskah wawancara, catatan lapangan, dokumen pribadi, catatan memo dan dokumentasi resmi lainnya. Sehingga menjadi tujuan dari penelitian kualitatif ini adalah ingin menggambarkan realita empiric di balik fenomena secara mendalam, rinci dan tuntas. Oleh karena itu penggunaan pendekatan kualitatif dalam penelitian ini dengan mencocokkan antara realita empiric dengan teori yang berlaku dengan menggunakan metode diskriptif.

\section{HASIL DAN PEMBAHASAN}

Dari hasil penelitianyang telah dilakukan maka penulis merasa ada beberapa yang perlu diperhatikan terkait implementasi kebijakan pengelolaan pertamanan di Kota Palangka Raya. Mengenai pengelolaan pertamanan di dalam Peraturan Daerah Nomor 03 Tahun 2006 berdasarkan hasil penelitian, maka dapat di katakana bahwa implementasi kebijakan pengelolaan pertamanan masih belum optimal. Walaupun demikian dinas cipta karya tata ruang dan perumaha melalu bidang pertamanan kota palangka raya semaksimal mungkin melaksanakan tugas dan tanggung jawab yang telah di berikan pemerintah kota Palangka Raya dengan mengarahkan seluruh sumber daya yang dimiliki.

Masih belum berjalannya implementasi dengan baik dikarenakan terdapat beberapa hal yang menjadi indicator implementasi kebijakan yang belum berjalan dengan maksimal. Salah satunya adalah indicator dari tujuan-tujuan kebijakan. Dalam hal ini diketehaui bahwa hal mendasar yang menjadi tujuan-tujuan dari adanya Peraturan Daerah Nomor 03 Tahun 2006 tersebut masih belum tercapai. Tujuan kebijakan tersebut salah satunya adalah untuk meningkatkan partisipasi masyarakat dalam hal pengelolaan pertamanan ini adalah untuk meningkatkan kualitas pertamanan yang ada, baik dalam hal varietas tanaman, kualitas kebersihan taman, dan juga infrastruktur taman. Sementara dilapangan menunjukan bahwa pengelolaan pertamanan masih belum berjalan sesuai dengan tujuan yang ingin dicapai. Rusaknya infrastruktur taman seperti bangku, tempat sampah, lampu penerangan pagar, lantau dan lain sebagainya menunjukan bahwa tujuan dari kebijakan masih belum tercapai dengan baik.

Kendala lain yang dihadapi Dinas Cipta Karya Tata Ruang dan Perumahan khususnya pada Bidang Pertamanan adalah pada indicator karakteristik badanbadan pelaksanaan, seperti petugas pengelolaan pertamanan yang masih minim baik dari segi kualitas dan juga kuantitas. Untuk saat ini petugas lapangan pengelolaan pertamanan berjumlah 21 orang termasuk I orang pengawas. Selain itu belum adanya tingkat pengawasan dalam bentuk permanen di area taman yang bertugas dalam mengawasi segala bentuk aktivitas di taman menyebabkan taman-taman di salahgunakan oleh sebagaian masyarakat khususnya pada malam hari, seperti minuman-minuman keras, mengkonsumsi obatobatan diluar resep dokter.

Rendahnya partisipasi masyarakat dalam rangka mengelola pertamanan yang ada di kota Palangka Raya menjadi salah satu permasalahan dalam pengimplementasian peraturan daerah tentang pengelolaan pertamanan di Kota Palangka Raya. Dalam hal ini indicator keberhasilan implementasi jika ditinjau dari aspek komunikasi antar lembaga pelaksanaan kebijakan dinilai masih belum maksimal.

Hasil peneltitian juga menyebutkan bahwa sosialisasi yang dibangun pihak Dinas Cipta Karya Tata Ruang dan Pertamanan Kota Palangka Raya kepada masyarakat masih belum dapat diterima masyarakat dengan baik, 
selain karena media informasi dan sosialisasi yang digunakan masih belum menarik perhatian masyarakat (papan perda dan baliho), jumlah media informasi yang terbatas, serta aktifitas sosilisasi mengenai pengellaan pertamanan yang dilakukan oleh pihak Dinas terkait dilakukan kurang lebih setahun sekali.

Kerjasama yang baik tentunya juga harus dibangun oleh Dinas Cipta Karya Tata Ruang dan Perumahan Kota Palangka Raya dengan beberapa instansi pemerintah Kota Palangka Raya lainnya dalam rangka pengimplementasian kebijakan pengelolaan pertamanan, seperti satuan polisi Pamong Praja yang bertugas dalam hal penertiban pelanggaran, Badan lingkungan hidup yang juga berwenang dalam mengelola kondisi lingkungan pertamanan, Dinas Kehutanan dan juga lembaga-lembaga swasta yang bergerak dibidang informasi public demi tercpainya kondisi pertamanan di Kota Palangka Raya yang lebih baik lagi

\section{KESIMPULAN}

Ukuran dasar-dasar dan tujuan kebijakan menunjukan bahwa pengelolaan pertamanan belum berjalan sesuai dengan tujuan yang ingin dicapai. Rusaknya beberapa infrastruktur taman seperti bangku, tempat sampah, lampu penerangan pagar, lantai dan lain sebagainya menunjukan bahwa tujuan dari kebijakan belum tercapai dengan baik. Hal tersebut dikarenakan kesadaran masyarakat yang sangat kurang untuk menjaga dan merawat area pertamanan.

Sumber-sumber kebijakan dalam hal ini bahwa Dinas Cipta Karya Tata Ruang dan Perumaham khususnya pada bidang pertamanan yang menangani pengelolaan pertamanan tidak mengalami kendala dalam anggaran rutin dan juga fasilitas sarana-sarana.

Komunikasi antar organisasi dan kegiatan-kegiatan pelaksana, lemahnya komunikasi yang dibangun Dinas Cipta Karya Tata Ruang dan Perumahan melalui Bidang
Pertamanan dalam hal memberikan sosialiasasi kepada seluruh masyarakat mengenai pengelolaan pertamanan, penegakkan aturan dan sanksi sesuai peraturan daerah nomor 03 tahun 2006 tentang pengelolaan kebersihan lingkungan dan pertamanan.

Karaketristik badan-badan pelaksanan seperti minimnya sumber daya manusia dalam hal kualifikasi baik dari kualitas dan juga kuantitas di bidang pertamanan serta belum adanya pengawasan untuk tingkat keamanan dan ketertiban ditaman-taman kota.

Kondisi ekonomi, social, dan politik masyarakat sangat mendukung dengan peraturan daerah yang mengatur pengelolaan pertamanan. Jika dilihat dari kondisi dampak kebijakan pengelolaan pertamanan bahwa masyarakat selalu menginginkan adanya pertamanan dengan aktifitas peningkatan keindahan dan keasrian tanam.

Kecenderungan implementor dalam setiap pelaksanaanya tidak lepas dari kendala yang dihadapi baik dalam ataupun dari luar. Dengan berbekal bentuk sumber daya yang ada Bidang Pertamanan Kota Palangka Raya selalu menjalankan tugas dan kewajibannya. Tanggung jawab, kerja sama serta kerja keras dilaksanakan oleh para petugas pertamanan serta para pegawai di bidang pertamanan Kota Palangka Raya.

\section{REFERENSI}

Agustino,Leo. 2008. Dasar-Dasar Kebijakan Publik. Bandung : CV. Alfabeta.

Herdiansyah, Haris. 20I0. Metodologi Penelitian Kualitatif. Jakarta : Salemba Humanika.

Kencana Syafiie, Inu. 2007. Ilmu Pemerintahan. Bandung : Alfabeta

Nugroho, Riant. 2009. Public Policy. Jakarta : PT Elex Media Komputindo.

Pasolong,Harbani. 20II. Teori Administrasi Publik. Bandung : Alfabeta.

Perda Daerah Kota Palangka Raya Nomor 03 Tahun 2006 Tentang Kebersihan Lingkungan dan Pengelolaan Pertamanan. 
Person, Wayne. 200I. Publik Policy-Pengantar teori dan Praktik Analisis Kebijakan. Jakarta. Prenada Media.

Subarsono, AG. 2005. Analisis Kebijakan Publik-Konsep Teori dan Aplikasi. Jakarta : Pustaka Pelajar.

Sugiyono. 2013. Metode Penelitian Kuantitatif, kualitatif, dan R\&D. Bandung : Alfabeta.

Tangkilisan, Hesel Nogi S. 2003. Kebijakan Publik yang Membumi. Yogyakarta : Lukman Offset.

Winarno, Budi. 2007. Kebijakan Publik Teori dan Proses. Yogyakarta : Media Pressindo. 